Habtamu Temesgen, Nyssen, J., Amanuel Zenebe, Nigussie Haregeweyn, Mengistie Kindu, Mulugeta Lemenih, Mitiku Haile, 2013. Ecological succession and land use changes in a lake retreat area (Main Ethiopian Rift Valley). Journal of Arid Environments, 91: 53-60.

\title{
Ecological succession and land use changes in a lake retreat area (Main Ethiopian Rift Valley)
}

Habtamu Temesgen, Jan Nyssen, Amanuel Zenebe, Nigussie Haregeweyn, Mengistie Kindu, Mulugeta Lemenih, Mitiku Haile

Habtamu Temesgen, Dilla University, Department of Land Resources Management, Dilla, Ethiopia; E-mail: habte023@yahoo.com

J. Nyssen (Corresponding author). Ghent University, Department of Geography, Krijgslaan 281, B-9000 Gent, Belgium. Email: jan.nyssen@ugent.be

Amanuel Zenebe. Mekelle University, Department of Land Resource Management and Environmental Protection, P.O.Box 231, Mekelle, Ethiopia, and K.U.Leuven, Division Soil and Water Management, B - 3001 Leuven, Belgium. Email: amanuelza@yahoo.com

Nigussie Haregeweyn. Mekelle University, Department of Land Resource Management and Environmental Protection, P.O.Box 231, Mekelle, Ethiopia. Email:

nigussie_haregeweyn@yahoo.com

Mengistie Kindu. Ethiopian Agricultural Research Institute, Forestry Research Centre, P.O.Box 20 30708, Addis Ababa, Ethiopia. Email: mengistiek@yahoo.com

Mulugeta Lemenih. Wondo Genet College of Forestry and Natural Resources, P. O. Box 128, Shashamane, Ethiopia. E-mail: elerohi@ yahoo.com.

Mitiku Haile. Mekelle University, Department of Land Resource Management and Environmental Protection, P.O.Box 231, Mekelle, Ethiopia. Email: gualmitiku@ yahoo.com

\begin{abstract}
In the semi-arid Main Ethiopian Rift Valley, ecological succession is related to continuous lake retreat. Human activity, through its impact on land use and cover, affects this ecological succession at various degrees. Through a remote sensing study, we explored how the drivers for LUCC have changed over the last decades and which impact this has on ecological succession.
\end{abstract}


Remote sensing data used include a Landsat MSS from 1973, a Landsat TM from 1986 and Landsat ETM+ from 2000; a conventional type of classification was used whereby supervised classification of the 2000 image was supplemented by unsupervised classification of the older images. Due to decreased rainfall and water abstraction for intense irrigated agriculture in its catchment, Lake Abijata lost $46 \%$ of its area between 2000 and 2006. On the emerged land, an ecological succession was observed along the environmental gradient of the retreating lake: emerged bare land, grassland, land with few scattered Acacia shrubs and open woodlands. Between 1986 and 2000, LUCC tendencies were totally reversed and woody vegetation decreased strongly, indicating increased human impact. This land degradation took place in a context of instable political situation, fuelwood extraction, higher population density and better communications.

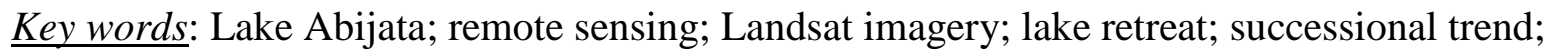
deforestation; Ethiopia

\section{Introduction}

Ecological succession is an orderly process of vegetation community development that involves change in species structure and community processes with time (Odum, 1971). In the Main Ethiopian Rift Valley (MERV), ecological succession is related to continuous lake retreat since some 5000 BP. Human activities, through their impact on land use and cover (LUC), also affect ecological succession at various degrees. LUC are continually changing owing to many factors. Whereas natural causes such as climatic variability (drought, heavy storms etc.), greenhouse impact and volcanic eruption may be important (Turner II et al., 1995; Serneels and Lambin, 2001), the majority of changes at contemporary time are however induced by human action 
(Turner II et al., 1995). Empirical investigations in the highlands of Ethiopia (Zeleke, 2000) have shown that an increase in population density results in the conversion of the forest into cultivated land or of cultivated land into badlands. It is as important to consider the impact of land improvement practices and infrastructure development on land use and cover changes (LUCC) (Nyssen et al., 2009). According to Turner II et al. (1995), both direct and indirect effects of these practices must be included in research.

Individual earth-surface cover types are distinguishable in terms of their spectral reflection characteristics. Landsat TM, SPOT and Aster satellites imagery is frequently used for land resources assessment. The advantage with Landsat is that it has recorded data since 1970s and can provide a historical data set to study LUCC changes in temporal perspective.

Computer assisted digital image processing to extract information involves image classification and accuracy assessment. Digital image classification tends to fall into two operational classes: supervised and unsupervised classification (Lillesand and Kiefer, 2000). In general, it has been recognised that satellite datasets and GIS have due importance in LUCC detection and the outcomes have been used for planning and decision making activities (Howard, 1991; Walsh et al., 2006). The digital data processed from the satellite images is supplemented with data from field interviews and discussions with local people and key informants (Xu et al., 2005). Hence, the aims of this study are to (a) extricate ecological succession and human activity as causative factors for LUCC, and (b) explore how the drivers for LUCC have changed over the last decades and which impact this has on ecological succession in the MERV.

\section{Research methods}

\subsection{Study area}

\subsubsection{Location}


The study area $\left(637 \mathrm{~km}^{2}\right)$ is located in the MERV, about $200 \mathrm{~km}$ south of Addis Ababa (Fig. A1, in the online appendix), between $38^{\circ} 24^{\prime}-38^{\circ} 42^{\prime} \mathrm{E}$ and $7^{\circ} 30^{\prime}-7^{\circ} 42^{\prime} \mathrm{N}$. About $80 \%$ of it is within Abijata Shala Lakes National Park (ASLNP). It is bounded by four lakes of tectonic or volcano-tectonic origin: Lake Ziway (1635 m a.s.1.), Lake Langano (1585 m a.s.1.), Lake Abijata (1580 $\mathrm{m}$ a.s.1.) and Lake Shala (1550 m a.s.1.) (Acocella et al., 2003). The elevation of the studied area ranges between 1580 and $1780 \mathrm{~m}$ a.s.l., with fairly level to gently sloping terrain.

\subsubsection{Climate}

The study area has a semi-arid climate (Umer and Bonnefille, 1991; Billi, 2002). Average annual rainfall in nearby Adamitullu station (half way between lakes Abijata and Ziway) is $768 \mathrm{~mm}$ (1980-2006). In most years, it is characterised by bimodal rainfall: very short and unreliable rain during the months April-May, while most of the rain occurs during three summer months (JuneAugust) and sometimes up to September (Eshete, 1999). Temperatures are relatively high with mean monthly maximum and minimum of $28^{\circ} \mathrm{C}$ and $13.8^{\circ} \mathrm{C}$ (Billi, 2002).

\subsubsection{Geology and hydrology}

The Ethiopian rift valley is part of the Afro-Arabian rift system, bounded by the Arabian plate in the north, the African plate to the west and the east. It is a funnel-shaped endorheic depression that opens up in the northeast into the Gulf of Aden and the Red Sea and continues southwards through the East-African Rift up to Mozambique (Acocella et al., 2003). The lithology is dominated by basalt, ignimbrite, lava, gneiss, lapilli tuff, volcanic ash and pumice as well as riverine and lacustrine alluvium that gives rise to pale colour, coarse textured and well drained light soils (Makin et al., 1975; Dainelli et al., 2001; Billi, 2002). The study area lies in a part of the MERV called lakes district, encompasses seven lakes of tectonic or volcano-tectonic origin 
(Coltorti et al., 2002). Lake Ziway is separated from Lake Langano by a dormant volcano mountain range. Ziway and Langano Lakes are outwardly linked to Lake Abijata by Bulbula and Horakelo rivers. Part of Jido River, normally draining to Lake Shala, overflows during the rainy season and also joins Lake Abijata through river Gogessa (Fig. A1, in the online appendix).

Lowering of lake levels had a strong effect on the exposure of parent material, and hence on soils, vegetation and land use. The abundant literature on late Quaternary rift lake level changes was systematised by Gasse and Fontes (1989) and later reviewed by Nyssen et al. (2004). They describe high lake levels before the Last Glacial Maximum (LGM - 30,000-27,000 ${ }^{14} \mathrm{C}$ years before present - BP), low levels during the LGM (22,000-12,000 BP), after which the lake levels rose again (Fig. 1). Since $5000 \mathrm{BP}$ there is a nearly continuous lake level lowering which was only interrupted by high stands between 2500 and 1500 BP (Nyssen et al., 2004).

\section{\#Fig. 1 approximately here\#}

\subsubsection{Soils}

In most places in the study area, soils derived from volcanic ash are observed. Mostly the ash has been reworked and occurs as lacustrine sediment. Local outcrops of cemented lapilli tuff (as documented by Coltorti et al., 2002) have a preferred occurrence at an elevation of 1600-1610 m a.s.1. allowing to correlate this lacustrine terrace (Dainelli et al., 2001) with the last relatively high lake level (2200 to 1600 BP, see Fig. 1).

The lake deposits of different ages are interbedded with pumice and classified as Andosols. They are coarse textured (loamy sand to fine sand), highly alkaline ( $\mathrm{pH}$ of 7.6-8.2) especially where high ionic strength has caused a precipitation of calcium carbonate. Their low bulk density and hence weaker structure render them vulnerable to wind and water erosion. The soils generally 
have low fertility and low organic matter with moderate nutrient retention capacity (Makin et al., 1975).

The extreme west of the study area (Alage campus) is however located on thick alluvium composed of reworked ignimbrites (Dainelli et al., 2001) that were deposited by Jido River. Its colour is more brownish than the lake sediment and it has a great susceptibility to gully erosion (visual observations).

\subsubsection{Vegetation}

The natural vegetation in most areas of this central part of the rift valley is sparse umbrellashaped woodland, classified as Acacia-Balanites woodland (Umer and Bonnefille, 1991) (Fig. A2, in the online appendix). The woodlands surrounding the four lakes were formed as a result of lowering of the water level since 5000 BP. The main tree species include Acacia Senegal (L.) Willd., A. tortilis (Forsk.) Hay., A. seyal Del. and Balanites aegyptica (L.) Del. accompanied by some shrubs such as Croton dichogamus Pax., Harisonia abyssinica Oliv., Terminalia brownii Pers., Sclerocarya birrea (A.Rich.) Hochst. and Acokanthera schimperi (DC.) Oliv. with grassdominated ground vegetation (Abdi, 1993; Eshete, 1999, Gebrekirstos et al., 2008). The woodland subsists mostly in a degraded state (Fig. A3, in the online appendix).

\subsubsection{Land use and farming system}

The study area is generally occupied by mostly pastoral Oromo people who came from around 100-km away highlands at both sides of the Rift Valley, as nowadays part of their dry season refuges in the better-watered highlands have been taken over for cultivation (Eshete and Ståhl, 1998). Formerly, cattle herding (sylvo-pastoralism) dominated the farming system of this area. These days, a mixed farming system that integrates cropping, fuel wood extraction and livestock 
(mostly cattle) is adopted in the area (agro-sylvo-pastoral system), but still herding is the main activity. Most grazing is free roaming on the vast communal grazing lands from which the lake retreated. In turn, crop production supplies crop residue as one of the basic feed sources for livestock. Farmers with no or less cattle rent out maize and sorghum fields immediately after harvest. The lessee will collect crop residues, pile it up on big trees between branches, and subsequently organize intensive grazing (Eshetu, 2003). As a consequence, it can be observed that topsoils of maize and sorghum fields are structurally destroyed and are composed of whitish fine dust.

Cattle manure is mainly used on gardens close to the homesteads, while the outfields, which will be considered in the present study, receive no manure. The major crop grown in the area is maize (Zea mays) which typically requires low labour input in cultivation. Other crops such as sorghum, green pepper, field pea and sweet potatoes do also occur in the area.

\subsection{Remotely sensed data and maps used}

Remote sensing data used in the research include a Landsat Multi-Spectral Scanner (MSS) from 1973, a Landsat Thematic Mapper (TM) from 1986 and Enhanced Landsat Thematic Mapper Plus (ETM+) from 2000. Satellite imagery from the same period of the year (end January, begin February) was used in this change detection study because this minimises discrepancies in reflectance caused by seasonal vegetation fluxes and sun angle differences (Bottomley, 1998). Lowest possible seasonal moisture content and lowest percent monthly cloud cover were decisive factors considered during the selection of available dataset scenes (Table 1). In addition, a quick image, a very recent (at the time of use - 2006) satellite image displayed for preview by Global Land Cover ((http://glcfapp.umiacs.umd.edu:8080/esdi/index.jsp), was used for the purpose of delineation of the recent lake boundary. Supplementary data sources used include: 
topographic maps, administrative map and map of the park. Topographic map sheets at scale of 1:50 000 and 1:250 000 (EMA, 1976a,b,c, 2004) were used for boundary delineation and navigation purpose, and supported ground truthing and training site establishment. \#Table 1 approximately here\#

\subsection{Image Processing}

Ground control points were collected for each LUC type (Table 2) at the centre of uniform LUC units (radius >100 m). Recognition of patterns in the data (training — sensu Mather, 1999) was performed through a supervised method in which sets of signatures that define a training sample were recognised. The signatures on the recent image that correspond to a class, and a maximum likelihood decision rule were used to assign the pixels in the image to the respective class (Gallego, 2004) whereby seven LUC classes were considered in image classification. Training sites were established for the recent image (ETM+) being supplemented by dwellers' confirmations to fill the six years gap between time of image acquisition and training site establishment. The classification of older images (MSS and TM) was based on integration of unsupervised classification and visual signature editions (ERDAS, 1999), involving the spectral values of the recent image that led us to signature collection for supervised classification. Then a class separability test was performed to evaluate the significance of difference (degree of separability) between LUC classes (Bottomley, 1998). We used the supervised maximum likelihood classification algorithm for all the images, which is generally recognised as the best classifier technique (Verbyla, 1995; Mather, 1999; Gautam et al., 2003). Maximum likelihood classification assigns a pixel to a particular class based on the higher covariance information.

Before producing the final output, the classified images were sieved, clumped and filtered. Clumping of cultivated land with trees and without trees was undertaken based on the results of 
the spectral separability test of ERDAS Imagine signature editor and the classified images were corrected for their isolated pixels and spatial coherence.

\#Table 2 approximately here\#

An accuracy assessment, determining the quality of the information derived from the remotely sensed data, was done using a separate set of 45 testing sites. An error matrix compares the relationships between known reference data (ground truth) and the corresponding classification results (Lillesand and Kiefer, 2000) and comprises overall accuracy, users' accuracy (the probability that a LUC class identified on the map is classified into the same category on the ground), and producer's accuracy (the probability that a LUC class identified on the ground is classified into the same category on the map) (Campbell, 2002).

\subsection{LUCC analysis and pattern detection}

The classified images were vectorised and exported to Arc Info GIS software version 3.52, where change matrices among the three LUC maps were established. Based on the matrices, patterns of degradation or succession were thoroughly investigated and compared between the study periods.

\section{Results and discussion}

\subsection{Land use and cover classification}

On the basis of the temporal and spatial data sets acquired LUC maps of the study area were prepared for 1973, 1986 and 2000 (Fig. 2, Table 3).

\#Fig. 2 approximately here\# 


\section{\#Table 3 approximately here\#}

The classification accuracy was assessed for the recent image (2000) with an overall accuracy level of $73.8 \%$ (Table 4). The lowest user accuracy of $25 \%$ was registered for the barren land class, which is attributed to the land emergence, since the lake showed a $46 \%$ reduction between 2000 and 2006.

\section{\# Table 4 approximately here\#}

In 1973 the highest proportion was covered by the lake (31\%). About one fourth of the study area was covered by sparse and heavily grazed woodland which became the greatest cover in $1986(31 \%)$. The vast lake retreat area, which was subjected to long term ecological succession, had due contribution for grazing land accounting $20 \%$ of the total area in 1973. The dense woodland including protected woodlands for various development activities was estimated at $12 \%$ in 1973 and increased by $5 \%$ at 1986. In 2000, however, the dense woodland has decreased to one third of its 1986 area $(7 \%)$. The LUC classes with smaller area throughout the study period are broad-leaved forest and cultivated land. The cultivated land cover recorded for 1973 was only $3 \%$. This is mainly attributed to the farming system of the community which is more focused on cattle rearing than cropping (Eshetu, 2003). In addition, the impact of Lakes Abijata and Langano makes the large newly emerged areas of land salt affected and crusted by calcium sulphate (which could be visually inferred from Landsat MSS image whereby the lake retreat mark is conspicuously detected). Thereby, the soil is left with low organic carbon and hence low water holding capacity, infiltration and soil fertility. Furthermore, it is also possible that wooded cropland might have been classified to woodland and some very shiny and bright agricultural land could have been misclassified as barren land during image classification. This is suggested by the observation that, immediately after harvest, agricultural fields are subjected to intensive grazing and left exposed and dusty. 
The second part of the study period shows a pattern of land use changes that is very different from the first period (Table 3, last columns). In 1973-1986, increases in woodland and decrease of barren land are indicators of ecological succession, whereas in 1986, LUCC tendencies are totally reversed, indicating increased human impact.

Changes in soil organic carbon (SOC) stock in the study area follow a similar trend: on average, it was assessed that there was $3966( \pm 1799) \mathrm{g} \mathrm{m}^{-2} \mathrm{SOC}$ in 2000 , against $4319( \pm 1835) \mathrm{g} \mathrm{m}^{-2}$ in 1986 and $4199( \pm 1866) \mathrm{g} \mathrm{m}^{-2}$ in 1973 (Nyssen et al., 2008).

\subsection{Current lake retreat}

Although LUC maps show that Lake Abijata's area decreased by 5.6 \% between 1973 and 1986, no change was registered from 1986-2000. This interruption in the general trend of lake level lowering could be due to the increased runoff coefficient resulting from decreased vegetation cover between 1986 and 2000. Supplemental information extracted from a quick image shows however a dramatic reduction by $46.5 \%$ between 2000 and 2006 (Fig. 3). Similar figures are mentioned in a separate study by Jansen et al. (2007).

\#Fig. 3 approximately here\#

\section{\#Fig. 4 approximately here\#}

A study of old maps by Billi (2002) concluded that, at current retreat rate, within less than 100 years L. Abijata will be totally dry. This projection could be reduced by more than half based on the retreat rate observed between 2000 and 2006. Legesse et al. (2004) modelled explanatory factors for lake retreat. Sometimes the Soda Ash factory is blamed for pumping an excessive amount of water (Gebre-mariam, 1998). Nevertheless, factory officials pointed to two basic reasons: the decreased discharge of Bulbula River (overflow of Lake Ziway into Lake Abijata) as Lake Ziway's water is increasingly used for irrigation, and underground flow to Lake Shala. 
Although it calls for investigation and is not new to this period, the probability of Lake Abijata infiltrating to the less elevated Lake Shala is also supported by Billi (2002). Discussions with farmers again point to the decreased discharge of Bulbula River, which is in accordance with observed large expansion of irrigated agriculture including vastly expanding floriculture on Lake Ziway's shore.

Observed rainfall reduction (Fig. 4), water pumping for soda ash production and especially abstraction for irrigation in the upper catchment around Lake Ziway are three recent developments that concur in lowering the lake level.

\#Table 5 approximately here\#

\subsection{Land use and cover changes}

The change matrix (Table 5) shows that broad-leaved forest increased by $0.6 \%$ during the first period (1973- 1986) and decreased by $0.7 \%$ during the second period (1986-2000) when it was basically changed to protected woodland (40\%), grazed woodland (35\%) and cultivated land (11\%). Field observations and discussions with local people showed that the change of broadleaved forest to protected woodland by $40 \%$ is due to the thinning of the broadleaved forest through removal of some of the big ficus trees for lumber that created a woodland structure and species composition similar to that of the protected woodland class. This land cover class mainly exists around Alage. Own observations and informal discussions with elders of the surroundings reveal that there was a good protection and conservation of the natural vegetation after the establishment of the "Children Amba" institution in 1980 (Alage) and it continued until the change of the government of Ethiopia in 1991. The reduction of this broad leaved forest is thus attributed to the encroachment exerted by the communities since 1991. Chuluun and Ojima 
(2002) also showed that increased human population and political reforms are most outstanding basic causes of LUC change in arid and semi-arid areas of Asia.

More importantly, protected and grazed woodlands increased by $5.2 \%$ and $4.1 \%$ during the first period and dramatically decreased by $10.6 \%$ and $5.8 \%$ during the second period. The change matrix analysis shows (Table 5) that protected woodland in 1986 was mainly converted to grazed woodland (41\%), grazing land (28\%) and some to cultivated land (7\%). Likewise, grazed woodland reduction is attributed to its conversion to grazing land (33\%) and cultivated land (9 $\%)$. This implies that overgrazing and charcoal production are efficient anthropogenic agents for wood cover reduction.

Among the major land use groups, a cumulative increment of $8.6 \%$ was registered for grazing land. An increase in the three woodland covers during the first period reduced the grazing land but this tendency was reversed in the second period (1986-2000). In the same way, cultivated land showed a net increment of $4 \%$. According to the informants and change matrix analysis, this was obviously due to the conversion of woodland (34\%) and grazing lands (39\%) to cultivated land.

In both periods, the apparently random conversion of most of the cultivated land to other land uses should not surprise, as shifting cultivation is a common practice in the area, whereby established fields are abandoned for longer periods during which ecological succession is allowed to take over.

Generally, a net area reduction is observed for woodland. This is thought to be due to: (1) the failure of the strength of institutions in the study area in conserving the protected woodlands which started during the transition period (1991/92) of "Derg" regime to the present government, (2) an increase in human and subsequently in cattle population and (3) charcoal extraction (Eshetu, 2003). Investigations by Muttitanon and Tripathi (2005) in the coastal zone of Ban Don 
Bay (Thailand) show that institutional and political change greatly affects sustainable resources management. In the study area, intense conflicts over boundaries between the Oromo people and bordering diverse ethnic groups of the Southern Peoples' Regional state have also resulted in weak implementation of land management policies by authorities at different levels.

\subsection{Patterns of land use and cover change (ecological succession versus land degradation)}

Two different patterns of change were distinguished in the study period: (1) increased areas of woody vegetation land classes and decreased barren land areas during the first study period, implying that there was an ecological succession during that period, and (2) a reduction in area of woody vegetation and an increase in barren land were observed in the second study period. Ecological succession, which is an orderly process of vegetation development, is reasonably directional and, therefore, predictable (Odum, 1971). In this perspective, the grass community development on the barren lake retreat area can easily be visualised from false colour composite displays of 1973 to 1986 . Similarly, statistics of change analysis between 1973 and 1986 reveal that barren land coverage shrunk from $7 \%$ in 1973 to $4 \%$ in 1986 and succeeding sparse wood and shrubland consumed $41 \%$ of the grazing land (Fig. A4, in the online appendix).

The ecological succession that took place on emerged lands (in a horizontal dimension, from old to recent images: emerged bare land, grassland, land with few scattered Acacia shrubs and open woodland) corresponds to a situation where the ecosystem is strongly zoned along an environmental gradient (Watt, 1947; Shugart et al., 1988), in this case the retreating lake.

The incidental increasing successional trend from 1973 to 1986 was shown to be hampered during the next period and even up to date (1986-2000/2006). As a result of LUCC indicated above, the three wood based classes significantly decreased during this period implying that deforestation had substantial contribution to land degradation (Haile and Gebre-Hiwot, 2002). 
More evidently, substantial proportions of grazing land gain were observed at the expense of woody vegetation through deforestation. Secondly, at constant lake size, $2.5 \%$ gain was registered for barren land which is most certainly attributed to the impact of overgrazing whereby grazing land is reconverted to barren land. Third, although it was less important during 1973-1986, throughout the study period, cultivated land was increased; by $3.2 \%$ during 19862000. Thus, agricultural expansion has an obvious contribution for hampering ecological succession. Informants around ASLNP headquarters confirmed that besides agricultural expansion, woodland deforestation is due to increased fuelwood (firewood and charcoal) sale to the nearby towns, which is spurred by the increasing consumption of fuelwood to produce "katikala", a local alcohol, in view of its demanding market at Arisi Negele and other towns including Addis Ababa.

\subsection{Drivers of land use and cover changes}

As the summarised results show (Table 5), during the period between 1973 and 1986, woody vegetation cover and grazing land increased with subsequent reduction of barren land. This implies that there was an ecological succession following lake retreat. Discussions with elders showed that the major underlying cause for the observed succession during the aforementioned period was attributed to the better environmental protection and sparse population density during the "Derg" regime period, as also demonstrated by Reid et al. (2000).

In contrast, a reduction of woody vegetation cover and an increase in cultivated land and barren land were observed between 1986 and 2000 (Table 3). Discussions with elders and experts of three institutions in the study area (Alage Agricultural Vocational Training College, Abernosa Cattle Ranch and Abijata Shala Lakes National Park) confirmed that the basic underlying causes 
of the changes are anthropogenic, particularly deforestation and overgrazing rather than climatic catastrophe.

Technological progress of the recent period which adopted improved agricultural inputs attracted the community to practice agriculture more widely and to extensively work with irrigated agriculture which exacerbated the lowering of Lake Abijata, as was also found by Jansen et al. (2007). These could result from accessibility of the area and betterment of infrastructure as modelled by Serneels and Lambin (2001) in Kenya, Narok District. Their model explained that spatial determinants (driving forces) prevail to explain the spatial distribution of different LUCC processes.

\section{Conclusions}

The LUCC observed are the cumulative effect of the interactions between social and environmental factors conditioned by the prevailing subsequent socio-economic changes that took place in the area. The pattern of changes notably differs between 1973-1986 and 1986-2000, being governed by the intensity of protection exerted before and after 1991, which marks the change in government in Ethiopia. Ecological succession took place between 1973 and 1986 on emerged lands in a horizontal dimension from old to recent image: emerged bare land, grassland, land with few scattered Acacia shrubs and open woodlands., However, overgrazing and deforestation for fuelwood production and cultivation have contributed to the degradation of vegetated areas since 1986. The continued deforestation of the vegetated areas in the study area, like other areas in the country, adversely affects the LUC and biodiversity resources. In light of the findings of this study the following issues are recommended for further investigation and also to be noted by policy makers and land use planners: 
1. Despite their significance for sustainable land resources management and planning, LUCC detections of Ethiopia have only been performed in a patchy form in space and time. Thus, sustainable development planning entails the spatial and temporal LUCC detection of the country.

2. Both ecological succession and land degradation are pointed out in this study as being governed by human activities and political reformation. However, ecological succession in the MERV has been overtaken by land degradation since 1986, which obliges for rehabilitation interventions.

3. Succession progress on lake retreat areas involves stunted Acacia plants (Fig. A4, in the online appendix), which are accompanied by aeolian deposits on the leeward side (Kocurek and Nielson, 1986; Bristow et al., 2000). Ways of using vegetation to decrease the prevailing wind erosion in the area need to be investigated.

\section{Acknowledgements}

The authors wish to thank Worku Zewde and Kefialew Sahile for their constructive comments and technical advice, as well as Ermiyas Aynekulu for his day-to-day advice and encouragement. We are indebted to Wondo Genet College of Forestry and Mekelle University library staff. Colleagues Temesgen Belay, Eshetu Yirsaw, Zeleke Kassa and Edo Barresa supported the field work. Mesku Deressa, Abebe Legesse and Temesgen Eshete provided climatic data and analysed soil samples. HT and JN were at Mekelle University when carrying out fieldwork. A research grant was provided by Alage TVET College. We thank especially the rural dwellers around Alage TVET and Lake Abijata for their hospitality and the numerous informations they provided. 


\section{References}

Abdi, M., 1993. Impact of human activity on Abijata-Shalla Lakes National Park ecosystem. MSc Thesis. Agricultural University of Norway.

Acocella, V., Korme, T., Salvini, F., 2003. Formation of normal faults along the axial zone of the Ethiopian Rift. Journal of Structural Geology 25, 503-513.

Billi, P., 2002. Geodynamic setting of the Ethiopian Rift. In: Dramis, F., Molin, P., Cippoloni, C., Fubelli, G. (eds), IAG international symposium on climate changes, active tectonics and related geomorphic effects in high mountain belts and plateaux, excursion guide of the pre-symposium field trip "Geomorphology of the Ethiopian Rift", 27-48.

Bottomley, B.R., 1998. Mapping rural land use \& land cover change in Carroll County, Arkansas utilizing multi-temporal Landsat Thematic Mapper satellite imagery. University of Arkansas. http://www.cast.uark.edu/local/brandon_thesis/index.html (accessed 1 April 2007).

Bristow, C.S., Chroston, P.N., Bailey, S.D., 2000. The structure and development of foredunes on a locally prograding coast: insights from ground-penetrating radar surveys, Norfolk, UK. Sedimentology 47, 923-944.

Campbell, J.B., 2002. Introduction to Remote Sensing, The Guilford Press, New York, 620 p.

Chuluun,T., Ojima, D., 2002. Land use change and carbon cycle in arid and semi-arid lands of East and Central Asia. Science in China (Life Sciences) 45, 48-54.

Coltorti, M., Corbo, L., Sacchi, G., 2002. Geomorphology and Quaternary evolution of the Main Ethiopian Rift. In: Dramis, F., Molin, P., Cippoloni, C., Fubelli G., IAG International Symposium on Climate Changes, Active Tectonics and Related Geomorphic Effects in High Mountain Belts and Plateaux, excursion guide of the Pre-Symposium Field Trip "Geomorphology of the Ethiopian Rift", 13-26.

Dainelli, N., Benvenuti, M., Sagri, M., 2001. Geological map of the Ziway — Shala Lakes basin (Ethiopia). Department of Earth Sciences, University of Florence, Italy.

EMA, 1976a. Topographic map of Ethiopia, 1:50,000 Bulbula sheet, 0738B3. Ethiopian Mapping Agency, Addis Ababa.

EMA, 1976b. Topographic map of Ethiopia, 1:50,000 Mito sheet, 0738A4. Ethiopian Mapping Agency, Addis Ababa.

EMA, 1976c. Topographic map of Ethiopia, 1:50,000 Zway sheet, 0738B1. Ethiopian Mapping Agency, Addis Ababa.

EMA, 2004. Topographic map of Ethiopia, 1:250,000 Hosa'ina sheet, NB 37-2. Ethiopian Mapping Agency, Addis Ababa.

ERDAS, 1999. ERDAS Field Guide. ERDAS Inc., Atlanta, Georgia, USA.

Eshete, G., 1999. Assessment of fuelwood resources in acacia woodland in the Rift Valley of Ethiopia: towards the development of planning tools for sustainable management. Doctoral Thesis, Swedish University of Agricultural Sciences, Umeå, Sweden.

Eshete, G., Ståhl, G., 1998. Functions for multi-phase assessment of biomass in acacia woodlands of the Rift Valley of Ethiopia. Forest Ecology and Management 105, 79-90.

Eshetu, M., 2003. Perceptions of local communities towards wildlife and protected areas of Ethiopia. Unpub. MSc thesis, Durrell Institute of Conservation and Ecology, University of Kent, Canterbury, UK.

Gallego, F. J., 2004. Remote sensing and land cover area estimation. International Journal of Remote Sensing 25, 3019-3047.

Gasse, F., 1998. Water resources variability in tropical and subtropical Africa in the past. In: Water resources variability in Africa during the XXth Century, Proceedings of the Abidjan '98 Conference. IAHS Publ. 252, 97-105. 
Gasse, F., Fontes, J.C., 1989. Palaeoenvironments and palaeohydrology of a tropical closed lake (Lake Asal, Djibouti) since 10,000 yr BP. Palaeogeography, Palaeoclimatology, Palaeoecology 69, 10-67.

Gautam, A.P., Webb, E.L., Shivakoti, G.P., Zoebisch, M.A., 2003. Land use dynamics and landscape change pattern in a mountain watershed in Nepal. Agriculture, Ecosystems and Environment 99, 83-96.

Gebrekirstos, A., Mitlöhner, R., Teketay, D., Worbes, M., 2008. Climate-growth relationships of the dominant tree species from semi-arid savanna woodland in Ethiopia. Trees 22, 631641.

Gebre-mariam, Z., 1998. Human Interactions and Water Quality in the Horn of Africa. Proceedings of the Symposium on Emerging Water Management Issues, Philadelphia, February 1998. http://www.aaas.org/international/africa/ewmi/zinabu.htm (accessed 3 June 2007).

Haile, M. and Gebre-Hiwot, K., 2002. Efforts to rehabilitate degraded lands in Tigray: the case of Enchemare. Journal of Natural Resources Management 11, 23-36.

Howard, J.A., 1991. Remote sensing of forest resources: Theory and practice. Chapman and Hall, Cambridge.

Jansen, H., Hengsdijk, H., Legesse, D., Ayenew, T., Hellegers, P., Spliethoff, P., 2007. Land and water resources assessment in the Ethiopian Central Rift Valley. Alterra-rapport 1587. Alterra, Wageningen, The Netherlands, $81 \mathrm{pp}$.

Kocurek, G., Nielson, J., 1986. Conditions favourable for the formation of warm-climate aeolian sand sheets. Sedimentology 33, 795-816.

Legesse, D., Vallet-Coulomb, C., Gasse, F., 2004. Analysis of the hydrological response of a tropical terminal lake, Lake Abiyata (Main Ethiopian Rift Valley) to changes in climate and human activities. Hydrological Processes 18, 487 - 504.

Lillesand, T.M., Kiefer, R.W., 2000. Remote sensing and image interpretation. Wiley, New York, USA.

Makin, M.J., Kingham, J.J., Waddams, A.E., Brichall, C.J., Tefera, T., 1975. Development prospects in the Southern Rift Valley. Land Resource Division, Ministry of Overseas Development, U.K. Vol. II

Mather, P.M., 1999. Computer processing of remotely-sensed images. An Introduction. Chichester: Wiley.

Muttitanon, W., Tripathi, N.K., 2005. Land use/land cover changes in the coastal zone of Ban Don Bay, Thailand using Landsat 5 TM data. International Journal of Remote Sensing 26, 2311-2323.

Nyssen, J., Poesen, J., Moeyersons, J., Deckers, J., Mitiku Haile, and Lang, A., 2004. Human impact on the environment in the Ethiopian and Eritrean Highlands - a state of the art. Earth Science Reviews 64, 273-320.

Nyssen, J., Temesgen, H, Lemenih, M., Zenebe, A., Haile, M., 2008. Soil organic C stock in a lake retreat area under increased human pressure (Main Ethiopian Rift Valley). Geoderma 146, 261-268.

Nyssen, J., Simegn, G., Taha, N., 2009. A permanent upland farming system under mutation: drivers of land use change in Bela-Welleh catchment (Wag, northern Ethiopian highlands). Soil and Tillage Research, 103: 231-238.

Odum, E.P., 1971. Fundamentals of Ecology. Saunders, Philadelphia, USA, 574 p.

Reid, R. S., Kruskal, R. L., Muthui, N., Andualem Taye, Wotton, S., Wilson, C. J., Woudyalew Mulatu, 2000. Land-use and land-cover dynamics in response to changes in climatic, 
biological and socio-political forces: the case of southwestern Ethiopia. Landscape Ecology 15, 339-355.

Serneels, S., Lambin F., 2001. Proximate causes of land-use change in Narok District, Kenya: a spatial statistical model. Agriculture, Ecosystems and Environment 85, 65-81.

Shugart, H.H., Bonan, G.B., Rastetter, E.B., 1988. Niche theory and community organization. Can. J. Bot. 66, 2634-2639.

Turner II, B.L., Skole, D., Sanderson, S., Fischer, G., Fresco, L., Leemans, R., 1995. Land-Use and Land-Cover Change (LUCC), Science/Research Plan. IGBP Report No. 35 and HDP Report No. 7. International Geosphere-Biosphere Programme and the Human Dimensions of Global Environmental Change Programme, Stockholm, Bonn.

Umer, M., Bonnefille, R., 1991. The recent history of vegetation and climate around Lake Langano (Ethiopia). Palaeoecology of Africa 22, 275-286.

Verbyla, L.D., 1995. Satellite remote sensing of natural resources. Lewis Publishers, New York, USA, 224 p.

Walsh, S.J., Entwisle, B., Ronald, R., Rindfuss, P.H., 2006. Spatial simulation modelling of land use/land cover change scenarios in northeastern Thailand: a cellular automata approach. Journal of Land Use Science 1, 5-28.

Watt, A.S., 1947. Pattern and process in the plant community. J. Ecol. 35, 1-22.

Xu, J., Fox, J. Vogler, J.B., Peifang, Z., Yongshou, F., Lixin, Y., Jie, Q., Leisz, S., 2005. Landuse and land-cover change and farmer vulnerability in Xishuangbanna Prefecture in Southwestern China. Environmental Management 36, 404-413.

Zeleke, G., 2000. Landscape dynamics and soil erosoin process modelling in the North-western Ethiopian highlands. African Studies Series A 16. Institute of Geography, University of Berne, Switzerland. 


\section{Tables}

Table 1. Satellite images used in LUCC detection

\begin{tabular}{lclll}
\hline Satellite instrument & No. of bands & $\begin{array}{l}\text { Ground } \\
\text { resolution }\end{array}$ & Acquisition date & path/row \\
& & & & \\
\hline Landsat MSS & 4 & $57 \mathrm{~m} * 57 \mathrm{~m}$ & $31 / 01 / 1973$ & $181 / 055$ \\
Landsat TM & 7 & $28.5 \mathrm{~m} * 28.5 \mathrm{~m}$ & $21 / 01 / 1986$ & $168 / 055$ \\
Landsat Enhanced TM+ & 7 & $28.5 \mathrm{~m} * 28.5 \mathrm{~m}$ & $05 / 02 / 2000$ & $168 / 055$ \\
& & & & \\
\hline
\end{tabular}


Table 2. LUC categories with number of GCPs used to establish the signature on the 2000 image

\begin{tabular}{llc}
\hline $\begin{array}{l}\text { Land cover/ } \\
\text { land use }\end{array}$ & General description & $\begin{array}{l}\text { No. of } \\
\text { GCPs }\end{array}$ \\
\hline $\begin{array}{l}\text { Broad-leaved } \\
\text { forest }\end{array}$ & $\begin{array}{l}\text { Areas dominated by broad-leaved trees including artificial plantation areas } \\
\text { (mainly in and around Alage TVET college) }\end{array}$ & 4 \\
$\begin{array}{l}\text { Protected / dense } \\
\text { woodland }\end{array}$ & $\begin{array}{l}\text { Areas covered by woody plants (Acacia-dominated), with an undergrowth } \\
\text { of grasses and shrubs. It may have a status of closed to semi-open canopy } \\
\text { (mainly in Abernosa cattle ranch, ASLNP headquarter and Alage TVET }\end{array}$ & 6 \\
college) & $\begin{array}{l}\text { Areas covered with sparse woody plants (Acacia-dominated), whose } \\
\text { undergrowth is heavily grazed. It includes also shrubland covered with }\end{array}$ & 6 \\
$\begin{array}{l}\text { Grazed } \\
\text { woodland and } \\
\text { shrubland }\end{array}$ & $\begin{array}{l}\text { Areas of land prepared for growing rainfed crops. This category includes } \\
\text { Cultivated land } \\
\text { cultivation; broadly spaced trees may occur }\end{array}$ & 8 \\
Arazing land & $\begin{array}{l}\text { Areas covered with natural pasture dominated by grasses; this class may } \\
\text { also include small shrubs } \\
\text { Areas of land without vegetation, either due to erosion and overgrazing or } \\
\text { due to recent emergence }\end{array}$ & 6 \\
Barren land & $\begin{array}{l}\text { Includes the lake, intermittent ponds, and other areas with shallow water } \\
\text { Water bodies and }\end{array}$ & 3 \\
\hline
\end{tabular}


Table 3. Distribution of LUC in 1973, 1986 and 2000

\begin{tabular}{|c|c|c|c|c|c|c|c|c|c|}
\hline \multirow[t]{2}{*}{ LUC type } & \multicolumn{2}{|c|}{1973} & \multicolumn{2}{|l|}{1986} & \multicolumn{2}{|l|}{2000} & \multicolumn{3}{|c|}{ LUCC (\%) } \\
\hline & Area (ha) & $(\%)$ & Area (ha) & $(\%)$ & Area (ha) & $(\%)$ & $1973-1986$ & $1986-2000$ & $1973-2000$ \\
\hline Broad-leaved forest & 379 & 0.6 & 755 & 1.2 & 302 & 0.5 & +0.6 & -0.7 & -0.1 \\
\hline Protected / dense woodland & 7696 & 12 & 10962 & 17 & 4183 & 7 & +5.2 & -10.6 & -5.5 \\
\hline Grazed woodland and shrubland & 16906 & 26 & 19488 & 31 & 15822 & 25 & +4.1 & -5.8 & -1.7 \\
\hline Cultivated land & 2023 & 3 & 2538 & 4 & 4602 & 7 & +0.8 & +3.2 & +4.1 \\
\hline Grazing land & 12713 & 20 & 11210 & 18 & 18156 & 28 & -2.3 & +10.9 & +8.6 \\
\hline Barren land & 4293 & 7 & 2560 & 4 & 4180 & 7 & -2.7 & +2.5 & -0.2 \\
\hline Water bodies and wetlands & 19855 & 31 & 16232 & 25 & 16506 & $26^{a}$ & -5.6 & +0.4 & -5.2 \\
\hline
\end{tabular}

${ }^{a}$ Including three small reservoirs existing at Alage 
Table 4. Summary of the accuracy assessment

Classified data $\quad$ Producer accuracy (\%) Users' accuracy (\%) Overall accuracy (\%)

\begin{tabular}{lcc}
\hline Unclassified & - & - \\
Broad-leaved forest & 75.0 & 100 \\
Protected/dense woodland & 66.6 & 80.0 \\
Grazed woodland & 66.7 & 66.6 \\
Cultivated land & 77.7 & 100 \\
Grazing land & 71.4 & 62.5 \\
Barren land & 50.0 & 25.0 \\
Water bodies and wetlands & 100 & $83 . .3$ \\
\hline
\end{tabular}


Table 5. LUCC matrix between the three LUC maps (1973, 1986 and 2000) (in \%)

\begin{tabular}{|c|c|c|c|c|c|c|c|}
\hline 1973 & $\begin{array}{l}\text { Broad- } \\
\text { leaved } \\
\text { forest }\end{array}$ & $\begin{array}{l}\text { Protected/ } \\
\text { dense } \\
\text { woodland }\end{array}$ & $\begin{array}{l}\text { Grazed } \\
\text { woodland }\end{array}$ & $\begin{array}{l}\text { Cultivated } \\
\text { land }\end{array}$ & $\begin{array}{l}\text { Grazing } \\
\text { land }\end{array}$ & $\begin{array}{l}\text { Barren } \\
\text { land }\end{array}$ & $\begin{array}{l}\text { Lake and } \\
\text { wetlands }\end{array}$ \\
\hline $\begin{array}{l}\text { Broad-leaved } \\
\text { forest }\end{array}$ & 34 & 39 & 17 & 4 & 1 & 0 & 5 \\
\hline $\begin{array}{l}\text { Protected/ } \\
\text { dense } \\
\text { woodland }\end{array}$ & 3 & 56 & 36 & 3 & 1 & 0 & 0 \\
\hline $\begin{array}{l}\text { Grazed } \\
\text { woodland }\end{array}$ & 0 & 30 & 61 & 4 & 4 & 0 & 0 \\
\hline $\begin{array}{l}\text { Cultivated } \\
\text { land }\end{array}$ & 1 & 11 & 53 & 16 & 16 & 3 & 0 \\
\hline Grazing land & 0 & 6 & 41 & 7 & 45 & 1 & 0 \\
\hline Barren land & 0 & 0 & 4 & 6 & 78 & 13 & 0 \\
\hline $\begin{array}{l}\text { Lake and } \\
\text { wetlands }\end{array}$ & 1 & 2 & 0 & 0 & 6 & 9 & 81 \\
\hline 2000 & $\begin{array}{l}\text { Broad- } \\
\text { leaved } \\
\text { forest }\end{array}$ & $\begin{array}{l}\text { Protected/ } \\
\text { dense } \\
\text { woodland }\end{array}$ & $\begin{array}{l}\text { Grazed } \\
\text { woodland }\end{array}$ & $\begin{array}{l}\text { Cultivated } \\
\text { land }\end{array}$ & $\begin{array}{l}\text { Grazing } \\
\text { land }\end{array}$ & $\begin{array}{l}\text { Barren } \\
\text { land }\end{array}$ & $\begin{array}{l}\text { Lake and } \\
\text { wetlands }\end{array}$ \\
\hline $\begin{array}{l}\text { Broad-leaved } \\
\text { forest }\end{array}$ & 10 & 40 & 35 & 11 & 3 & 1 & 0 \\
\hline $\begin{array}{l}\text { Protected/ } \\
\text { dense } \\
\text { woodland }\end{array}$ & 1 & 22 & 41 & 7 & 28 & 1 & 0 \\
\hline $\begin{array}{l}\text { Grazed } \\
\text { woodland }\end{array}$ & 0 & 6 & 51 & 9 & 33 & 1 & 0 \\
\hline $\begin{array}{l}\text { Cultivated } \\
\text { land }\end{array}$ & 1 & 6 & 22 & 27 & 32 & 11 & 0 \\
\hline Grazing land & 0 & 1 & 3 & 10 & 69 & 16 & 1 \\
\hline Barren land & 0 & 3 & 2 & 12 & 9 & 72 & 3 \\
\hline $\begin{array}{l}\text { Lake and } \\
\text { wetlands }\end{array}$ & 0 & 0 & 0 & 0 & 0 & 0 & 100 \\
\hline 2000 & $\begin{array}{l}\text { Broad- } \\
\text { leaved } \\
\text { forest }\end{array}$ & $\begin{array}{l}\text { Protected/ } \\
\text { dense } \\
\text { woodland }\end{array}$ & $\begin{array}{l}\text { Grazed } \\
\text { woodland }\end{array}$ & $\begin{array}{l}\text { Cultivated } \\
\text { land }\end{array}$ & $\begin{array}{l}\text { Grazing } \\
\text { land }\end{array}$ & $\begin{array}{l}\text { Barren } \\
\text { land }\end{array}$ & $\begin{array}{l}\text { Lake and } \\
\text { wetlands }\end{array}$ \\
\hline $\begin{array}{l}\text { Broad-leaved } \\
\text { forest }\end{array}$ & 23 & 64 & 23 & 11 & 4 & 2 & 1 \\
\hline $\begin{array}{l}\text { Protected/ } \\
\text { dense } \\
\text { woodland }\end{array}$ & 2 & 22 & 59 & 9 & 14 & 1 & 0 \\
\hline $\begin{array}{l}\text { Grazed } \\
\text { woodland }\end{array}$ & 0 & 9 & 51 & 9 & 30 & 1 & 0 \\
\hline $\begin{array}{l}\text { Cultivated } \\
\text { land }\end{array}$ & 0 & 7 & 27 & 19 & 40 & 7 & 0 \\
\hline Grazing land & 0 & 2 & 10 & 9 & 71 & 5 & 0 \\
\hline Barren land & 0 & 3 & 2 & 10 & 42 & 33 & 0 \\
\hline $\begin{array}{l}\text { Lake and } \\
\text { wetlands }\end{array}$ & 0 & 1 & 1 & 2 & 4 & 8 & 83 \\
\hline
\end{tabular}




\section{Figure captions}

Fig. 1. Levels of Ziway-Shala lakes during the Holocene. The $\mathrm{x}$-axis represents the age (in $10^{3}$ years BP); the $\mathrm{y}$-axis is the elevation of the lake level (in $\mathrm{m}$ above the present level of Lake Shala). Reprinted from Gasse (1998), with permission from IAHS Press.

Fig. 2. LUCC in the study area between 1973 and 2000. Numerous linear features, more or less parallel to the shore of Lake Abijata correspond to successive shore lines during the lake's regression.

Fig. 3. Area of Lake Abijata as obtained from satellite imagery. Data for 2006 are from a quick image of January 2006 (http://glcfapp.umiacs.umd.edu:8080/esdi/index.jsp)

Fig. 4. Correspondence between lake area (lower curve) and yearly rainfall (Adamitullu station) with trendline (bold) 


\section{Figures}

Figure 1.

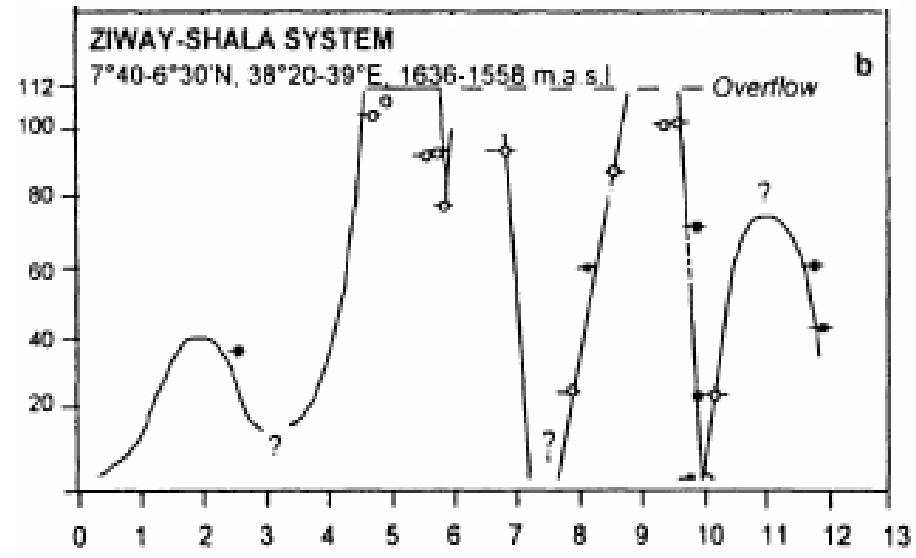



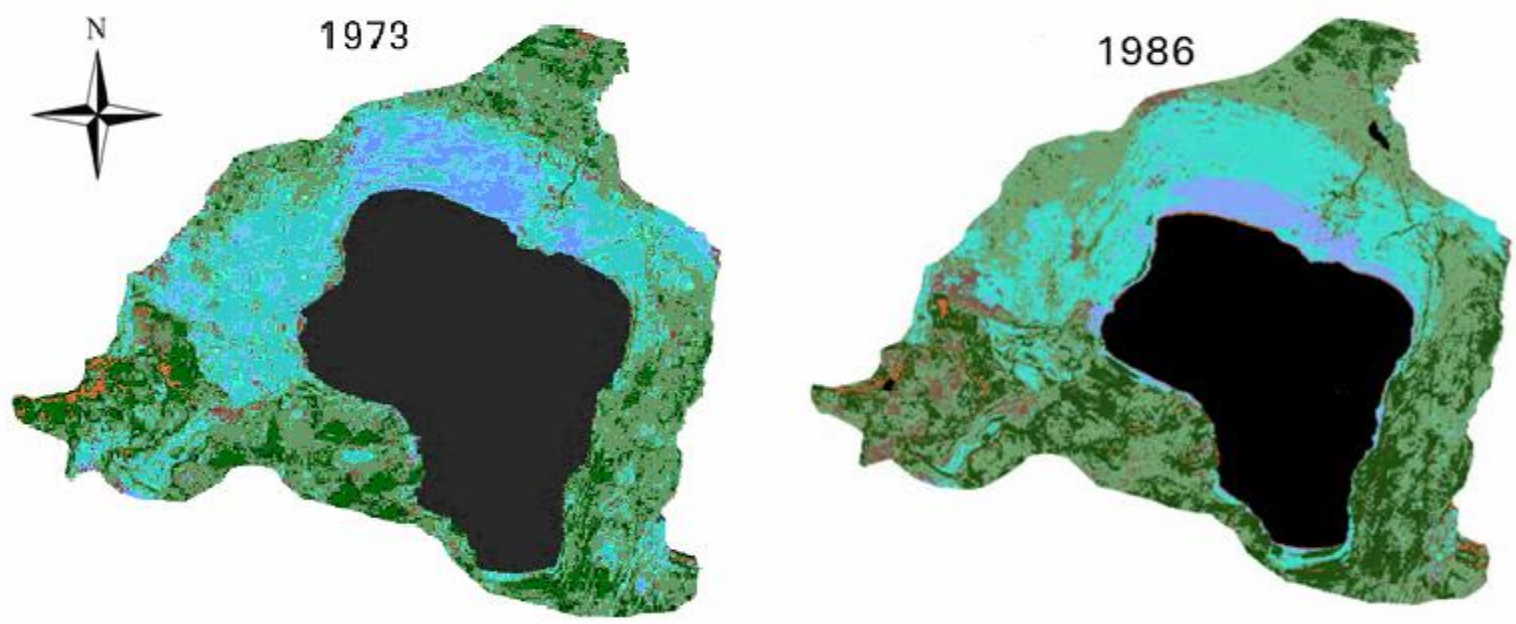

Figure 2.

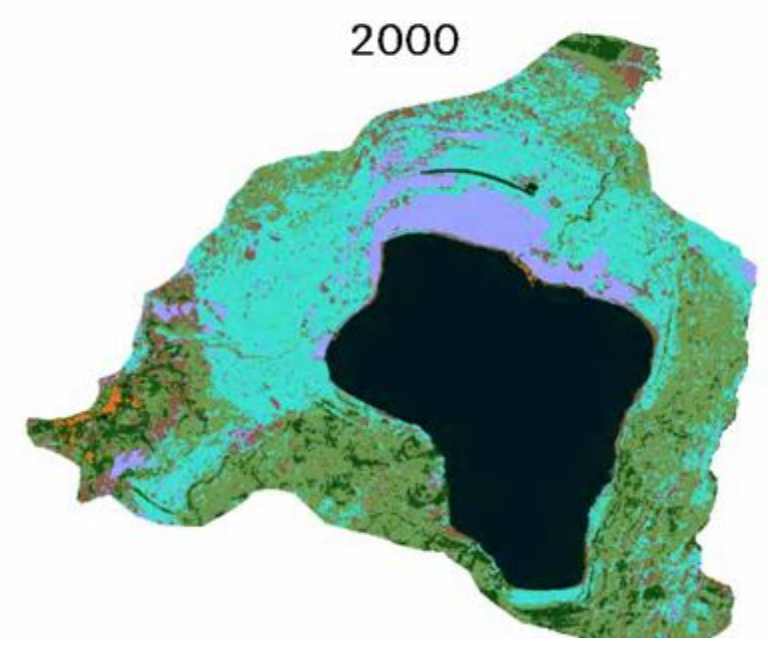

\section{Map Key}

Broad Leaved Forest

Protected Woodl and

Grazed Woodl and

cultivation Land

Grazing Land

Barren Land

Lake/Wet Land

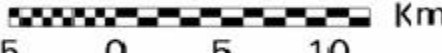


Figure 3.

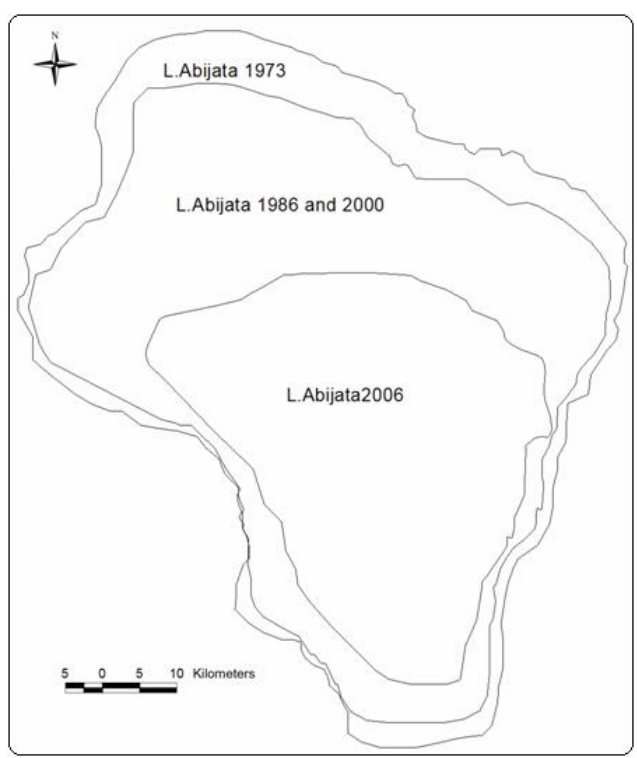


Figure 4.

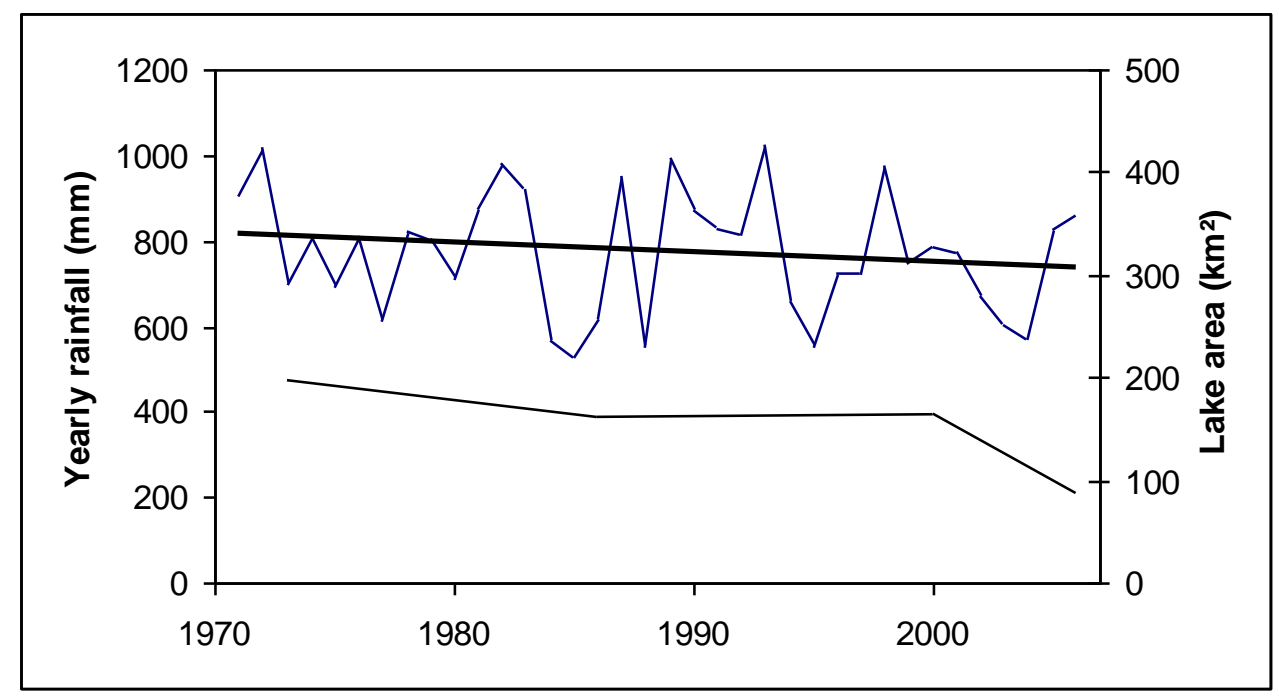

